\title{
WYBRANE ETYCZNE ASPEKTY REALIZACJI BADAŃ WŚRÓD OSÓB Z NIEPEŁNOSPRAWNOŚCIAMI I ICH BLISKICH
}

\section{Marta Sałkowska*}

Abstrakt

Artykuł podejmuje zagadnienia związane z wybranymi etycznymi i praktycznymi aspektami prowadzenia badań wśród osób z niepełnosprawnościami i ich bliskich, stanowiących grupę wrażliwą społecznie. Autorka analizuje konsekwencje tej wrażliwości dla procesu badawczego. Omawia istotność podejmowanego problemu badawczego zarówno dla rozwoju wiedzy akademickiej, jak i dla osób badanych. Rozważa uwarunkowania uzyskiwania świadomej zgody na udział w badaniu. Stawia pytania o granice wywiadu socjologicznego oraz zaangażowania badawczego.

Słowa kluczowe: etyka, grupa wrażliwa społecznie, osoby z niepełnosprawnościami, badania jakościowe

\section{CARRYING OUT RESEARCH AMONG PERSONS WITH DISABILITIES AND THEIR RELATIVES - SELECTED ETHICAL ISSUES}

Abstract

The paper tackles issues related to selected both ethical and practical aspects of conducting research among persons with disabilities and their relatives that constitute a vulnerable social group. The author analyzes its consequences in the research process, discusses the significance of the research problem undertaken both for the development of academic knowledge and for research participants, and analyzes the conditions for obtaining informed consent. Limits of sociological interview and researcher's engagement are also discussed.

Keywords: Ethics, vulnerable social group, persons with disabilities, qualitative research

* Dr Marta Sałkowska, Collegium Civitas, e-mail: marta.salkowska@civitas.edu.pl 
Wprowadzenie

Niniejszy artykuł zawiera rozważania na temat zagadnień etycznych związanych z realizacją badań z udziałem osób z niepełnosprawnością i ich bliskich. Nie jest jednak moim celem analiza skodyfikowanych zasad czy reguł prowadzenia badań zawartych w rozmaitych kodeksach czy wytycznych ${ }^{1}$, lecz refleksyjne spojrzenie na dylematy etyczne, które napotykam w swojej praktyce badawczej. Niniejsze rozważania opieram na badaniach, które indywidualnie lub zespołowo prowadziłam w środowisku osób z niepełnosprawnościami.

Artykuł ma zatem poniekąd charakter autoetnograficzny, gdy z perspektywy zdobytego doświadczenia oraz wiedzy o sobie jako o badaczce spoglądam na poszczególne etapy badań, w które byłam zaangażowana. Badania, na podstawie których buduję swoją (auto)refleksję miały charakter w równym stopniu akademicki (indywidualne wywiady jakościowe z matkami osób z zespołem Downa), aplikacyjny (badania w środowisku osób z niepełnosprawnościami, ich bliskich oraz pracowników socjalnych w gminie Słupno) oraz realizowane były na zlecenie publicznych instytucji (badanie na temat asystentów osobistych realizowane na zlecenie Biura Rzecznika Praw Obywatelskich)².

Należy zaznaczyć, że kwestie etyczne, o których piszę dotyczą głównie badań jakościowych, szczególnie zaś pogłębionych wywiadów indywidualnych, gdy badacz czy badaczka bezpośrednio kontaktują się z osobą z niepełnosprawnością lub jej bliskimi. W badaniach ilościowych mniej jest możliwości zaistnienia trudnych, problematycznych etycznie sytuacji w „terenie” - nawet jeśli badania dotyczą gromadzenia

\footnotetext{
' Na przykład Kodeks etyki socjologa (2012) Polskiego Towarzystwa Socjologicznego, http://www.pts. org.pl/wp-content/uploads/2016/04/kodeks.pdf.

${ }^{2}$ Wyniki poszczególnych badań dostępne są w następujących publikacjach: Sałkowska M. (2015); Badania $w$ działaniu. Raport z badań jakościowych $i$ ilościowych wykonanych $w$ ramach projektu Innowacje - przedsiębiorczość - rozwój (2012), (red.) Smosarski A., Centrum Wspierania Aktywności Lokalnej CAL, Warszawa; Bielińska M., Bieliński J., Sałkowska M. (2017), Asystent osobisty osoby z niepełnosprawnościq zapotrzebowanie na miarę Konwencji o prawach osób z niepełnosprawnościami, „Biuletyn RPO” nr 5.
} 
danych „wrażliwych”, sytuacja badania ilościowego ma zdecydowanie bardziej formalny i uporządkowany charakter3.

Wyjaśnienia wymagać też może wybór tych, a nie innych aspektów realizowania badań w tak szczególnym środowisku. Należy jasno zaznaczyć, że jest to mój subiektywny wybór. Z perspektywy czasu i zdobytego doświadczenia widzę, że właśnie te kwestie miały dla mnie jako dla badaczki oraz dla procesów badawczych niezwykle istotne znaczenie. Dlatego też to właśnie je zdecydowałam się opisać.

Oczywiście te aspekty nie są szczególne dla badań realizowanych wśród grup wrażliwych społecznie, lecz dotyczą po prostu badań z udziałem ludzi. Jednakże w obliczu niewielu dostępnych danych ilościowych na temat niepełnosprawności oraz badawczej eksploatacji środowiska (o czym dokładniej piszę później), kluczowe wydaje się zwrócenie uwagi właśnie na etyczne aspekty procesu badawczego realizowanego w tej grupie. Owe etyczne aspekty przenikają się tutaj z opisami praktyk badawczych i jest to zabieg zamierzony. Wszak sposób prowadzenia badań wynika z ich etycznych założeń i to właśnie one obecne są na każdym etapie procesu badawczego.

Czytelnikom należy się też słowo wyjaśnienia na temat autorefleksyjnego czy też autoetnograficznego charakteru niniejszego tekstu. Absolutnie nie uważam się za metodologiczną wyrocznię w etycznych kwestiach prowadzenia badań w ogóle, czy też w dziedzinie disability studies w szczególności. Nie jest oczywiście tak, że nikt poza mną nie zajmuje się tym tematem. Kwestia niepełnosprawności jest tematem podejmowanym w socjologii. Analizowana jest z różnych perspektyw teoretycznych i metodologicznych, gromadzone są dane ilościowe

\footnotetext{
3 Inną sprawą jest bardzo ograniczony zakres dostępnych danych statystycznych na temat sytuacji osób z niepełnosprawnościami. Bariery w gromadzeniu danych na temat tego środowiska opisane są w: Raport dotyczacy wdrażania art. 31 Konwencji o prawach osób niepełnosprawnych w Polsce: statystyka i zbieranie danych (2017), (red.) Grabowska I., http://www.pfon.org/images/dodatki/2017_konwencja _raport/RT_art31_statystyka.pdf.
} 
i jakościowe4. Niepełnosprawność w ostatnim czasie bywa również przedmiotem debaty publicznej, najczęściej stając się nim na chwilę, podczas protestów opiekunów.

I to właśnie owo chwilowe zainteresowanie mediów i opinii publicznej tematem, związane z protestami opiekunów osób z niepełnosprawnościami, wyznacza istotny kontekst niniejszych refleksji. O niepełnosprawności coraz częściej się „mówi”, można też zaobserwować wzmożone akademickie zainteresowanie tematem (nie tylko w postaci gromadzenia statystyk, ale również nowych interpretacji zjawiska). Artykuł stanowi przestrzeń do podzielenia się refleksjami dotyczącymi własnego warsztatu badawczego, który dotyka obszaru coraz bardziej intrygującego zarówno akademicko, społecznie, jak i kulturowo.

Społeczna wrażliwość osób z niepełnosprawnościami i ich bliskich oraz jej konsekwencje dla realizacji badań

Osoby z niepełnosprawnością i ich bliscy tworzą grupę wrażliwą społecznie i trudno dostępną. Jej wrażliwość polega w dużej mierze na podwójnej stygmatyzacji widocznej szczególnie w sytuacji matek osób z zespołem Downa czy też w ogóle opiekunów (a przede wszystkim opiekunek) osób z niepełnosprawnością (Liamputtong 2007: 3).

\footnotetext{
4 Wystarczy wspomnieć chociażby o następujących publikacjach: Upośledzenie w społecznym zwierciadle (1997) (red.) Gustavsson A., Zakrzewska-Manterys E., „Żak”, Warszawa; Agnieszka KumanieckaWiśniewska (2006), Kim jestem? Tożsamość kobiet upośledzonych umysłowo”, „Żak”, Warszawa; Niepełnosprawność intelektualna a style życia. Perspektywy podmiotowe, wybory życiowe, systemy usług w Szwecji, Norwegii i w Polsce (2003), (red.) Gustavsson A., Tøssebro J., ZakrzewskaManterys E., IFiS PAN, Warszawa; Społeczne problemy osób niepełnosprawnych(2002), (red.) Sikorska J.,IFiS PAN, Warszawa; Sekułowicz M. (2000), Matki dzieci niepełnosprawnych wobec problemów życiowych, Wydawnictwo Uniwersytetu Wrocławskiego, Wrocław; Woynarowska A. (2010), Niepełnosprawność intelektualna w publicznym i prywatnym dyskursie, Oficyna Wydawnicza Impuls, Kraków; Zakrzewska-Manterys E. (2010), Upośledzeni umysłowo. Poza granicami społeczeństwa, Wydawnictwo Uniwersytetu Warszawskiego, Warszawa; idem (1995), Down i zespół wq̨tpliwości. Studium z socjologii cierpienia, Semper, Warszawa 1995: Ostrowska A. (2015), Niepełnosprawni w społeczeństwie 1993-2013, IFiS PAN, Warszawa.
} 
Z jednej strony, podstawą piętnowania może stać się sam fakt bycia matką osoby z zespołem Downa (lub inną niepełnosprawnością)5. Wobec takiej kobiety uaktualnia się cały repertuar uprzedzeń i stereotypów, wraz z obwinianiem jej za niepełnosprawność intelektualną dziecka oraz, niekiedy, doszukiwaniem się „kary bożej” lub „złego prowadzenia się".

$\mathrm{Z}$ drugiej strony - kluczowe z punktu widzenia sytuacji życiowej kobiety są konsekwencje „specjalnego macierzyństwa”. Niekiedy z powodu niewydolnego systemu wsparcia czy też polityki społecznej, kobieta ogranicza swoją aktywność „tylko” do pełnienia roli społecznej matki. W tym szczególnym przypadku bycie matką oznacza również bycie, między innymi, fizjoterapeutką, rehabilitantką i logopedą.

Niemniej są to takie role, które realizowane są w przestrzeni prywatnej, w domu. Kontrowersje wokół kolejnych sejmowych protestów rodziców i opiekunów dzieci i dorosłych osób z różnymi niepełnosprawnościami ukazały jak znaczący jest to problem. Opiekunowie, a w szczególności matki-opiekunki, osób niepełnosprawnych bardzo często są zmuszeni do pozostania w domu, co powoduje wykluczenie z innych, pozadomowych sfer życia. Natomiast różnorodność ról społecznych, które jednostki wypełniają, pozytywnie wpływa na ich poczucie własnej wartości oraz możliwości i odwagę w stawianiu oporu stygmatyzacji i jej konsekwencjom (Thoits 2011: 19).

Wykluczenie osób badanych z uczestnictwa w sferze pozaprywatnej utrudnia badaczowi dostęp do nich, co może je dodatkowo stygmatyzować. $Z$ kolei utrudniony dostęp skutkuje mniejszym zasobem rzetelnych informacji na tematy związane z sytuacją osób z niepełnosprawnością i ich bliskich, a więc brakiem wiedzy większości „normalsów”, którzy nie mają doświadczenia kontaktu z niepełnosprawnością (zawodowo lub

5 Szczegółowo sytuację matki osoby z zespołem Downa opisuję w Sałkowka M. (2015), Matka Downa. Piętno. Znaczenia. Strategie, Zakład Wydawniczy NOMOS, Kraków. 
prywatnie). Tworzy się błędne koło wykluczenia i stygmatyzacji, ponieważ brak wiedzy powoduje bardzo często stereotypowe i krzywdzące postrzeganie oraz traktowanie.

Brak szeroko dostępnych wyników badań, z którym spotkałam się na początku realizacji badań wśród matek osób z zespołem Downa - w roku 2009 - ma swoje poważne konsekwencje w sposobie przygotowania do prowadzenia wywiadów.

Badania z udziałem bliskich osób z niepełnosprawnością intelektualną oczywiście były i są realizowane i wiedziałam o tym. Nie wiedziałam jednak, że to środowisko jest aż tak badawczo „eksploatowane”. Okazało się, o czym dowiedziałam się od jednej z osób wprowadzających mnie do środowiska (tzw. gate keepera), że do jej instytucji ciągle zgłasza się ktoś, kto chce robić badania, głównie pedagogiczne i psychologiczne, realizowane w większości przez studentów piszących prace dyplomowe. Przede wszystkich przeprowadzane są badania ilościowe ankiety z matkami, ojcami, dziećmi, rodzeństwem, wujostwem, na prawie wszystkie tematy.

Stanęłam zatem przed wyzwaniem przekonania potencjalnych osób badanych do udziału w moim jakościowym socjologicznym badaniu. Byłam na spotkaniu, przygotowałam odpowiednią informację o badaniu, w której opisałam, jaki jest jego cel, na czym polega uczestnictwo, jakie są moje zobowiązania i prawa osób badanych. Nie bez znaczenia był też podpis promotora rozprawy, który na pewno uwiarygodnił mój projekt badawczy. W innych sytuacjach, gdy prosiłam o udzielenie wywiadu, spotykałam się z odpowiedziami typu: wypełnić ankietę, ile to zajmie, znów jakieś badanie? Zdałam sobie sprawę, że matki osób z niepełnosprawnością intelektualną regularnie biorą udział w badaniach i są tym zwyczajnie zmęczone ${ }^{6}$. Jednak mimo badawczego wyeksploatowania

\footnotetext{
${ }^{6}$ Zjawisko eksploatowania środowiska osób z niepełnosprawnościami w ogóle zasługuje na zdecydowanie większą uwagę - z rozmów z koordynatorami projektów społecznych kierowanych do osób z niepełnosprawnościami wynika, że bardzo trudno w tym konkretnym środowisku znaleźć uczestników projektu, ponieważ projektowa oferta jest bardzo liczna.
} 
środowiska, nie otrzymałam wielu odmów udziału. Większość badanych reagowała entuzjastycznie - część z nich sama zgłaszała się do udziału w projekcie, odpowiadając na ogłoszenie umieszczone na forum internetowym.

Zasady, ramy i granice - co to jest wywiad socjologiczny?

Badania realizowane $\mathrm{w}$ grupie wrażliwej społecznie wymagają wiele cierpliwości, delikatności, ale też dokładnego wyjaśnienia ich zasad. Konieczne jest wyraźne zaznaczenie granic i ram tej konkretnej sytuacji. Uczestnicy badania muszą oczywiście poznać jego cel, obowiązki i zobowiązania badacza. Należy też zapewnić ich o poufności i anonimizacji danych oraz pozyskanych informacji. To wszystko potrzebne jest do uzyskania od nich świadomej zgody na udział w badaniu.

Pogłębione wywiady z matkami osób z zespołem Downa prowadziłam zarówno w Polsce, jak i w Norwegii . Zaobserwowałam różnice w zakresie formalizacji kwestii etycznych. W Trondheim wizytujący badacze przed przystąpieniem do realizacji badania muszą przedstawić opinię stosownej komisji etycznej z macierzystej uczelni (lub promotora, gdy takiej komisji nie ma). W Polsce przyjmuje się, że to promotor, grupa seminaryjna lub zespół badawczy pełnią rolę weryfikującą projekt, również pod względem stosowania się do etycznych zasad (Ciuk, LatusekJurczak 2012: 25-26). Formalizacja procesu otrzymywania zgody na realizację badania lub jej brak, znajdują swoje odzwierciedlenie w sposobie uzyskiwania świadomej zgody od osób badanych.

Norweskie uczestniczki badania nie były zdziwione, gdy prosiłam je o podpisanie formularza zgody na udział w badaniu, który zawierał ich

7 Realizacja badań w Norwegii możliwa była dzięki dofinansowaniu przez Fundusz Stypendialny i Szkoleniowy dwóch pobytów badawczych w Trondheim - w 2009 i 2011 roku. 
prawa oraz moje zobowiązania zarówno wobec osób badanych, jak i zgromadzonego materiału. Zdziwienia nie wzbudzała także zgoda na nagrywanie rozmowy.

Mnie natomiast zaskoczył fakt, że w ogóle nie musiałam wyjaśniać celu nagrywania, nie musiałam przekonywać - wręcz przeciwnie dla uczestniczek oczywiste było, że wywiad jest nagrywany.

Ta postawa względem wywiadów i badań mogła być spowodowana doświadczeniem w uczestnictwie w badaniach społecznych. Dostęp do osób badanych w Norwegii uzyskiwałam za pośrednictwem badaczy zatrudnionych na miejscowym uniwersytecie, którzy sami zajmowali się realizacją badań w środowisku osób niepełnosprawnych. Zatem moje pierwsze doświadczenia związane ze zdobywaniem dostępu oraz z uzyskiwaniem zgody na udział w badaniu były bardzo pozytywne. Osoby badane, mimo potencjalnego zmęczenia i znużenia byciem „odpytywanym”, entuzjastycznie reagowały na propozycję udzielenia wywiadu, niektóre z nich same się zgłaszały.

Teraz myślę, że taka postawa wynika w dużej mierze z zaangażowania badaczy i pracowników naukowych, którzy rzetelnie realizują badania z udziałem samych osób niepełnosprawnych oraz ich bliskich. Być może także osoby badane dostrzegają realne efekty ich uczestnictwa w projektach badawczych - nie tylko w postaci publikowanych artykułów czy książek akademickich, ale również jako wpływ na sposób wspierania osób z niepełnosprawnościami i ich bliskich.

W Polsce wśród moich gate keeperów była logopeda prowadząca zajęcia w ośrodku dla osób niepełnosprawnych, psycholog z ośrodka wczesnej interwencji, pracownicy stowarzyszenia dla rodzin osób z zespołem Downa. Korzystałam również z prywatnych kontaktów oraz umieściłam stosowne ogłoszenie na forum internetowym. Większość polskich uczestniczek była zaskoczona koniecznością podpisania formularza zgody na udział w badaniu, niektóre bez przekonania zgadzały 
się na nagrywanie wywiadu, jedna uczestniczka w ogóle nie zgodziła się na użycie dyktafonu8 ${ }^{8}$.

Zastanawiałam się, z czego wynika taka różnica w postawie matek z Polski i z Norwegii wobec udziału w badaniach społecznych. Być może ma tu znaczenie poziom zaufania społecznego (osoby badane mogą obawiać się, że ktoś wykorzysta gdzieś ich wypowiedzi, bez zapewnienia anonimowości), ogólnie negatywna opinia na temat badań i badaczy. Podejrzewam również, iż niestety nie jest powszechną praktyką uzyskiwanie pisemnej zgody na udział w badaniu, głównie z obawy o odmowę uczestnictwa.

Warto zaznaczyć, że kontrakt zawarty pomiędzy osobą realizującą badanie a osobą badaną ma efekt formalizujący całą sytuację i nadający jej bardzo konkretne ramy. Przede wszystkim dokładnie definiuje ją jako wywiad socjologiczny, a nie terapeutyczny. Stawia osobę realizującą badanie w roli osoby zadającej pytania, poszukującej konkretnych informacji w określonym badawczym celu. Osoba badana z kolei występuje nie jako klient terapeuty, a informator, uczestnik badania na określony temat. Mimo dokładnego wyjaśnienia, na czym polega wywiad oraz na ile to możliwe wyraźnego wyznaczenia granic naszego zaangażowania oraz profesjonalnej postawy, nie jest możliwe uniknięcie terapeutycznych aspektów samej rozmowy.

Należy jednak pamiętać, że jako socjolożki i socjologowie nie mamy kompetencji, aby udzielać terapeutycznego wsparcia. To, co możemy i powinniśmy zrobić to zadbać o możliwie największy komfort i poczucie bezpieczeństwa osób badanych. Niezbędna też jest dobra relacja. Czasem trzeba dać coś od siebie, aby wzbudzić zaufanie - wywiad socjologiczny jest interakcją polegającą na wymianie. I nie powinien oznaczać

\footnotetext{
${ }^{8}$ Mimo braku zgody na nagrywanie wywiad został przeprowadzony. Mam jednak świadomość, że nie udało mi się zanotować dokładnie wszystkich odpowiedzi tej Uczestniczki badania. Dlatego też informacje od niej uzyskane są zdecydowanie mniej reprezentowane w analizach - również z obawy przed błędnym zrozumieniem jej wypowiedzi.
} 
instrumentalnego traktowania osób badanych (por. Ciuk, Latusek-Jurczak 2012: 33-34).

Należy spojrzeć na tę sytuację w innych kategoriach. Za chwilę będziemy z badanymi rozmawiać o bardzo osobistych doświadczeniach, być może będzie to dla nich pierwsza możliwość szczerej wypowiedzi na temat ich życia. Zatem muszą oni coś o nas wiedzieć, muszą wiedzieć, komu będą opowiadać swoją historię. Nieraz opowiadałam matkom osób z zespołem Downa o mojej rodzinie, o moim synu. Podobnie jak moje rozmówczynie byłam matką, dzięki czemu więcej mogłam zrozumieć, być może kobiety mogły mi więcej powiedzieć niż powiedziałyby mężczyznom albo bezdzietnej kobiecie. Zresztą jak zaczynałam realizację badania, nie miałam jeszcze dzieci i gdy porównuję wywiady sprzed narodzin i po narodzinach, to widzę znaczące różnice w sposobie zadawania pytań, w mojej wrażliwości.

W procesie uzyskiwania zgody na udział należy uczynić jeszcze jedno niezwykle istotne rozróżnienie - wywiad socjologiczny nie jest wywiadem środowiskowym, na jego podstawie nie zostanie przydzielone wsparcie psychologiczne, materialne ani socjalne. Zauważyłam to, gdy w zespole realizowaliśmy badanie na zlecenie Biura Rzecznika Praw Obywatelskich dotyczące asystentów osobistych dla osób z niepełnosprawnościami. Badanych szukaliśmy między innymi za pośrednictwem różnych organizacji pozarządowych, pomocowych. Mnóstwo osób dzwoniło, nawet po zakończeniu badania, z pytaniem, czy mogą skorzystać z usługi asystenta osobistego.

Zatem już w informacji o badaniu powinniśmy wyraźnie zaznaczyć, czemu ma ono służyć i na czym polega w nim udział. Niewątpliwie dla sposobu definiowania sytuacji badawczej przez osoby badane znaczenie ma instytucjonalizacja samego badania. Jeśli zleceniodawcą jest Ośrodek Pomocy Społecznej czy też Biuro Rzecznika Praw Obywatelskich, to mogą oni oczekiwać, że w wyniku udziału w badaniu uzyskają oni jakieś wymierne korzyści. Natomiast, gdy badanie ma charakter akademicki, 
naukowy, to ewentualne korzyści mogą mieć raczej niewymierny, choć nie mniej ważny, charakter. Zgoda świadoma, ale czyja?

Z uzyskiwaniem świadomej zgody na udział w badaniu (zarówno ustnej, jak i pisemnej) powiązane są dylematy dotyczące tego, jak szczegółowo informować badanych o celach badania, sposobach analizy, założeniach teoretycznych. Naszym obowiązkiem jako badaczy jest oczywiście udzielenie wyczerpujących informacji, jeśli badani ich potrzebują. $\mathrm{Na}$ tym etapie, badacz musi przekazać tyle wiadomości, aby osoba badana zrozumiała, jaki jest cel badania. Nie trzeba przedstawiać założeń teoretycznych (chyba, że respondent zapyta) oraz detali związanych z analizą. Wystarczy tyle informacji, aby badany mógł wyrazić świadomą zgodę na udział w badaniu.

Problem pojawia się, gdy osobą badaną ma być osoba z taką niepełnosprawnością lub chorobą, która uniemożliwia jej samodzielne podjęcie decyzji. Zadaniem badacza jest w takiej sytuacji w jak najprostszy sposób wytłumaczyć, na czym polega badanie lub uzyskać zgodę od opiekuna takiej osoby. Powinniśmy jednak dokładać starań, aby umożliwiać osobom z niepełnosprawnością świadomy udział w badaniu.

To jest bardzo delikatna kwestia, która nabrała ogromnego znaczenia podczas realizacji badania dotyczącego asystentów osobistych dla osób z niepełnosprawnościami (na zlecenie Biura Rzecznika Praw Obywatelskich). Jednym z celów badania było rozeznanie potrzeb osób z różnymi niepełnosprawnościami w zakresie korzystania z asysty. Wśród osób badanych miały znaleźć się również osoby z różnym stopniem niepełnosprawności intelektualnej. Ta konkretna grupa jest szczególnie trudno dostępna, ponieważ kontakt z nią prawie zawsze zapośredniczony jest przez rodziców, opiekunów, różnych specjalistów.

Często tłumaczone to jest możliwymi trudnościami w komunikacji z potencjalną osobą badaną. Rodzice niekiedy chcą mówić niejako w imieniu swoich (dorosłych) dzieci z niepełnosprawnością intelektualną. Założenia naszego badania wykluczały jednak taką możliwość. 
W efekcie nie udało się zrealizować zaplanowanej liczby wywiadów z osobami z niepełnosprawnością intelektualną.

Należy tu zaznaczyć szczególną rolę gate keeperów lub opiekunów, którzy mogą mieć wpływ na ostateczną decyzję osoby badanej. Zadaniem badacza jest upewnienie się, czy udział w badaniu na pewno jest dobrowolny i czy osoba badana rozumie, na czym ten udział polega (wraz z możliwością wycofania się z wywiadu w każdej chwili).

Część wywiadów realizowana była z osobami z niepełnosprawnością intelektualną mieszkającymi w jednym z Domów Pomocy Społecznej (DPS). Osoby te zostały wskazane przez pracowników DPS (dyrekcję i psychologa) według opisanych przez zespół badawczy kryteriów społeczno-demograficznych. Na początku wywiadu dokładnie tłumaczono badanym zasady i dopytywano o dobrowolność udziału. Jednak, pomimo uzyskania zgód na udzielenie wywiadu, zastanawiam się, na ile udział tych osób był dobrowolny i świadomy, a na ile wynikał z relacji władzy w DPS i konieczności podporządkowania się woli psychologa czy też może z chęci spełnienia jego oczekiwań.

Podobną kwestię podnosi Jakub Niedbalski (2009) opisując etyczne aspekty prowadzenia obserwacji w domu pomocy społecznej dla osób z niepełnosprawnością intelektualną. W tym przypadku jawna obserwacja uczestnicząca została wybrana właśnie ze względu na potencjalne trudności komunikacyjne podczas realizacji wywiadów. Jednak, jak zauważa Autor, wątpliwości budzą pytania o realną możliwość zapewnienia badanym intymności, odpoczynku od badania podczas przebywania w instytucji opiekuńczej.

Zatem szczególnie w przypadku grup trudno dostępnych oraz wyjątkowo wrażliwych społecznie należy dokładnie przyglądać się motywacjom osób badanych. Trzeba zastanowić się, czy osoby te miały realną możliwość odmowy udziału w badaniu. Ponadto, należy również refleksyjnie dobierać nie tylko osoby badane, ale również gate keeperów, aby mieć pewność, że nie będziemy wykorzystywać ich uprzywilejowanej 
pozycji do wywierania wpływu na potencjalnych uczestników badania (Ciuk, Latusek-Jurczak 2012: 28-29).

Trudności w zakresie zapewnienia możliwości uczestnictwa w badaniu występują również w sytuacji wywiadu z osobą z niepełnosprawnością słuchu. Gdy badacz nie zna języka migowego musi korzystać albo z pomocy tłumacza (co oprócz dodatkowych kosztów oznacza osobę trzecią podczas wywiadu), albo z usługi zdalnego tłumaczenia na język migowy.

Podczas uzyskiwania od osób badanych świadomej zgody na udział, stosowałam często strategię „płytkiego ukrywania” (Lofland i in. 2009: 75-76). Badanie prezentowałam w kategoriach ogólnych, a nie szczegółowych. Uznałam bowiem, że wszystko mogę wyjaśnić, jeśli pojawią się dodatkowe pytania. Same wywiady były już wystarczająco skomplikowane, realizowane zazwyczaj w ramach układu prywatnego, do którego dostęp jest bardzo trudny. Nie chciałam zatem wprowadzać dodatkowych komplikacji.

O temacie badania i jego celu staram się informować w prosty sposób, unikałam naukowego żargonu, specjalistycznego języka. Gdy realizowałam badanie wśród matek osób z zespołem Downa mówiłam zgodnie $\mathrm{z}$ rzeczywistością, że pracuję nad rozprawą doktorską, której tematem są doświadczenia matek dzieci, nastolatków i dorosłych osób z zespołem Downa. Celowo nie używałam pojęcia „piętno”, mimo że było ono kluczowe z punktu widzenia analizy wyników. Nie chciałam sugerować kierunku moich założeń i interpretacji. Nie chciałam również, aby moje rozmówczynie poczuły się niekomfortowo. Uczestniczki badania były informowane o tym, że moim obowiązkiem jest ochrona ich prywatności, że wywiad jest anonimowy.

Mówiłam ponadto, iż w każdej chwili mogą wycofać się z udziału, mogą odmówić odpowiedzi na dane pytanie, możemy przerwać rozmowę. Unikanie akademickiego czy też profesjonalnego żargonu umoż- 
liwia również zminimalizowanie ryzyka teoretyzowania przez osoby badane, które mogłyby przestać mówić o własnych doświadczeniach (Ciuk, Latusek-Jurczak 2012: 26).

O różnych rodzajach manipulowania informacjami o badaniach, o ich rzeczywistych celach i o tych celach, które mają przyciągać i interesować osoby badane pisze Adrianna Surmiak (2016), Jak zauważa Autorka, manipulowanie informacjami o rzeczywistym charakterze badań wpływa na to, co potencjalni badani myślą o celach badania, jak sobie wyobrażają ich „naturę”.

Okazuje się jednak, że owe manipulacje informacjami o badaniu są uznawane za etyczne lub nie w zależności od kodeksu etycznego obowiązującego w określonej dziedzinie badań (etnologia, antropologia, socjologia). Tym bardziej zatem ciężar odpowiedzialności za sposób prezentacji badania oraz uzyskanie możliwie jak najbardziej świadomej zgody spoczywa na badaczu i na jego osądzie konkretnych sytuacji badawczych.

Temat ważny, ale dla kogo?

Brak dostępu do wyników tych wszystkich badań, które zostały zrealizowane, ale nie zostały upowszechnione (w ramach wszelkich prac dyplomowych) może mieć konsekwencje w ocenie istotności obranego problemu badawczego.

Pytanie o istotność to, jak zauważa Uwe Flick (2010: 124), jest jednym z pierwszych pytań i zagadnień etycznych, z którymi powinien zmierzyć się badacz projektując badanie. Już na etapie problematyzacji powinniśmy zadać sobie pytanie: czy ktoś już to zbadał? Jeśli tak, to nie ma sensu badać tego ponownie. Być może są dostępne dane, z których możemy skorzystać? Rzecz w tym, aby nie angażować badanych niepotrzebnie. Dlatego też tak ważne jest solidne przygotowanie do badań, zarówno od strony teoretycznej, jak i przeglądu danych zastanych. 
Oprócz istotności związanej z pogłębieniem wiedzy akademickiej na wybrany temat, rozważyć należy istotność poruszanych kwestii dla samych osób badanych. Decydując się na realizację badania z grupą wrażliwą społecznie powinniśmy założyć, że nasze badanie zmieni coś w życiowej sytuacji uczestników badania (Liamputtong 2007: 1011). Zmianę oczywiście rozumiemy jako sprawę pozytywną - zakładamy, że udział w badaniu poprawi sytuację uczestników badania.

Czy to nasze przekonanie ma przełożenie na rzeczywistość? Czy może tylko w ten sposób usprawiedliwiamy to, że „wchodzimy z butami” w najbardziej osobiste zakamarki doświadczenia życiowego osób badanych, że poruszamy kwestie, których oni sami często nie dotykają w rozmowach z innymi osobami? Co, oprócz naukowej czy też badawczej ciekawości, może uzasadniać nasze zainteresowanie najbardziej intymnymi doświadczeniami uczestników badania? Czy nasze badanie przyniesie jakieś korzyści, a w najlepszym wypadku nie przyniesie żadnych szkód?

O wyborze tematu w dużej mierze decyduje, gdy mamy swobodę $\mathrm{w}$ podejmowaniu wybranych problemów badawczych, temperament badacza, a niekiedy przypadek. Gdy wybieramy temat związany z osobami, które znajdują się gorszej sytuacji, musimy również zdecydować po czyjej stronie się opowiemy. Czy decydujemy się, aby poprzez nasze badanie, niejako udzielić głosu tym, którzy zazwyczaj nie mają takiej możliwości? Czy będziemy po stronie tych, którzy na przykład decydują o kształcie polityki społecznej? Czy też raczej po stronie tych, którzy są klientami, odbiorcami usług społecznych zaprojektowanych przez tych pierwszych?

To też w znacznej mierze kwestia naszego temperamentu oraz naszej gotowości do zaangażowania się, do wzięcia na siebie odpowiedzialności. Czy jako badacze możemy opowiadać się po jednej ze stron? Czy samo skoncentrowanie się na doświadczeniach jednej ze stron jest już opowiedzeniem się? 
Przyjmując czyjąś perspektywę narażamy się oczywiście na zarzut stronniczości, braku obiektywizmu w ocenie sytuacji. Howard Becker (1967) zauważył, że taki zarzut najczęściej pojawia się, gdy bierzemy pod uwagę doświadczenie tzw. zwykłych ludzi, a nie ekspertów. Becker, korzystając z terminologii zaczerpniętej z opisu relacji hierarchicznej, sytuuje takich zwykłych ludzi na miejscu podwładnych, a ekspertów, urzędników, specjalistów - na miejscu przełożonych. Becker proponuje, aby nie stawiać sobie pytania o to, czy stajemy po jakiejś stronie, lecz - po czyjej stronie stajemy, ponieważ prawie zawsze przyjmujemy czyjąś perspektywę, odwołujemy się do czyichś doświadczeń. $Z$ tego właśnie względu zaleca on solidne przygotowanie do badania, gotowość do odpierania zarzutów o stronniczość oraz przystępowanie do realizacji badania bez sentymentów.

Nie powinniśmy jako badacze rezygnować z badania jakiegoś problemu tylko dlatego, że jest on dla nas niewygodny albo obawiamy się, iż wyniki okażą się kłopotliwe. Przyjęcie perspektywy „podwładnych” oznacza udzielenie im głosu ${ }^{9}$. Za pośrednictwem badacza osoby wykluczone z dyskursu mogą wyrazić swoją opinię, ponieważ badacz w tym aspekcie jest bardziej uprzywilejowany. Badacza może chcieć wysłuchać jakiś dziennikarz, badacz ma większy autorytet. Badacz oraz naukowość, którą nadaje danej kwestii, podnosi jej rangę.

A może należy postawić sprawę inaczej, tak jak czynią zwolennicy paradygmatu teorii krytycznej - czy jako badacze możemy być po stronie innej niż osób słabszych, nieuprzywilejowanych? Powinniśmy korzystać z możliwości wynikających z zajmowanych przez nas pozycji i naszymi badaniami „udzielać głosu” osobom, które w inny sposób nie mogą się wypowiedzieć (por. Creswell 2007).

Oczywiście niezwykle trudno jest oszacować, czy i jak badanie poprawi sytuację osób badanych i im podobnych. Czy jego wyniki rzeczywiście

9 W przypadku matek osób z niepełnosprawnościami wymiar ten nabrał dodatkowego znaczenia, gdy one same wyszarpnęły sobie to prawo i rozpoczęły protest w budynku parlamentu. 
wpłyną na zmianę postaw społecznych, usprawnią system usług społecznych, polityki społecznej? Czy uda się zmniejszyć stopień wykluczenia społecznego i dyskryminacji rodzin z dzieckiem niepełnosprawnym?

Poszukując korzyści wynikających z całego projektu badawczego, należy również doszukiwać się ich na poziomie jednostkowym. Być może powinniśmy postawić sobie pytanie - w jaki sposób na udziale w badaniu skorzystają osoby badane? Jedna uczestniczka powiedziała, iż może jej historia pomoże innym kobietom w podobnej sytuacji. To motywowało ją do udziału w badaniu. Zachęcała ją również córka podając ten sam argument.

Poza tym, udzielenie wywiadu może być pierwszą możliwością opowiedzenia o tym, jak to jest być matką osoby z niepełnosprawnością intelektualną, jak to jest być osobą z niepełnosprawnością? Nadania tej historii własnego znaczenia, opowiedzenia jej ze swojej perspektywy, we własnych słowach, używając własnych określeń, a nie tych z profesjonalnych, specjalistycznych słowników.

W tym sensie udział w badaniu może nabrać emancypacyjnego i upodmiotawiającego charakteru (por. Chase 2009: 42). Z drugiej strony, niektórzy badacze postulują konieczność uszanowania „prawa osób badanych do niewiedzy" (por. Ciuk, Latosek-Jurczak 2012, s. 34), czyli nie nakłaniania do zwierzeń czy refleksji, do których by nie doszło, gdyby badani nie zgodzili się na udział w badaniu.

Takie podejście wywołuje wiele pytań, dotyczących również bardzo praktycznych aspektów całego procesu badawczego, np.: jak rekrutować osoby badane? Jak możemy ocenić na etapie rekrutacji, czy badaniem nie naruszymy tego „prawa do niewiedzy”? Czy nie możemy założyć, że skoro osoba dorosła, poinformowana o celu badania oraz możliwości wycofania się w każdej chwili wywiadu, po naszym upewnieniu się, że zrozumiała, na czym jej udział ma polegać, wyraża świadomą zgodę, to znaczy, że zgadza się również na potencjalne trudności emocjonalne 
z tym związane (np. przywołanie trudnych wspomnień, doświadczeń, ponowne ich przeżywanie)?

Emocje

Ze względu na wrażliwość poruszanych kwestii badacz musi być przygotowany na emocjonalne reakcje osób badanych. Znajomy psycholog poradził mi, abym zawsze miała przy sobie paczkę chusteczek - gdyby uczestniczka badania zaczęła płakać. Gest, jakim jest podanie chusteczki pokazuje, że realizujący wywiad akceptuje emocje rozmówcy, nie zaskakują go i może poczekać aż ten się uspokoi i będzie mógł kontynuować rozmowę. Byłam zatem przygotowana na to, że rozmowa może wywołać u osoby badanej silne emocje. Zgodziłam się na to, byłam też w stanie przewidzieć, w którym momencie wywiadu może to nastąpić.

Emocje badanych mniej mnie zaskoczyły niż moje - to na nie nie byłam dobrze przygotowana i z nimi trudniej mi było sobie poradzić. Psychologowie mają superwizje, podczas których anonimowo omawiają trudne przypadki, doradzają sobie nawzajem jak postępować w określonych sytuacjach, opowiadają, jak oni sami czuli się podczas rozmowy z klientem - opisują zatem swoje emocje. Socjologowi również towarzyszą emocje podczas wywiadów, zwłaszcza wywiadów pogłębionych dotyczących trudnych, osobistych tematów.

Niekiedy przeprowadzaniu wywiadów, wysłuchiwaniu historii życiowych towarzyszyło poczucie winy wynikające $\mathrm{z}$ tego, że ja sama mam pełnosprawne dziecko i że znajduję się w dużo lepszej sytuacji niż większość uczestniczek badania. Niejednokrotnie odczuwałam złość w stosunku do osób badanych. Nie zgadzałam się z ich sposobem rozumienia sytuacji, niepełnosprawności ich dziecka. Nie mogłam zrozumieć, dlaczego postępują w taki, a nie inny sposób. Starałam się nie okazywać tych uczuć. Oczywiście wiedziałam, że nie mam prawa oceniać postępowania badanych. Mimo to wywoływało ono silne emocje. 
Dlatego też prowadziłam dziennik badawczy, w którym zapisywałam swoje odczucia, opinie. Dzięki temu po jakimś czasie mogłam spojrzeć na notatki z dystansem i zrozumiałam, że moje rozmówczynie postępowały najlepiej, jak potrafiły. Dawały z siebie tyle, ile były w stanie. Wszystkie chciały jak najlepiej dla swojego dziecka, chociaż każda rozumiała to na swój sposób.

Myślę, że konieczna jest świadomość i gotowość na emocje towarzyszące badaniu spraw wrażliwych. Niezbędna okazuje się ciągła refleksyjność badacza, analizowanie sytuacji wywiadu, ponieważ to w trakcie rozmowy wydarzają się trudne sytuacje, w których niekiedy trzeba szybko podjąć decyzję - pytać dalej czy lepiej „odpuścić”? Co jest ważniejsze - wierność scenariuszowi czy samopoczucie osoby badanej? Za każdym razem badacz musi zorientować się, gdzie leżą granice tematyczne konkretnego rozmówcy. Powinien dołożyć wszelkich starań, aby tych granic nie naruszać (Flick 2010: 129-130).

Oczywiście jest to bardzo trudne zadanie, gdyż granice intymności u prawie każdego uczestnika badania przebiegają w inny sposób. Są osoby, które nie czują się skrępowane opowiadaniem o bardzo osobistych doświadczeniach. Ale są też takie, które przez całą rozmowę, mimo wysiłków czynionych przez badacza, pozostają spięte, zerkają na dyktafon.

Według mnie, priorytetem w realizacji badań z udziałem osób z grup wrażliwych społecznie, jest dobre samopoczucie badanych. Kilka razy musiałam rezygnować z zadawania kolejnych pytań, ponieważ widziałam, że jestem już niebezpiecznie blisko wspomnianej tutaj granicy. Nie od każdej kobiety udało mi się uzyskać wszystkie informacje, nie udało mi się zadać wszystkich pytań. Szczególnie trudnym obszarem była seksualność dorosłych osób z zespołem Downa. Jako, że jest to temat bardzo intymny i kłopotliwy dla matek, nie zawsze decydowałam się na dopytywanie, które narażałoby uczestniczki badania na jeszcze większy stres. Poza tym, sam temat jest na tyle obszerny i obarczony rozmaitymi 
uprzedzeniami, że powinien stać się raczej przedmiotem odrębnego badania.

Ogólnie rzecz biorąc, główna zasada realizowania badań z udziałem ludzi powinna brzmieć „po pierwsze nie szkodzić”. Na taką elastyczność i gotowość do rezygnacji z poruszania niektórych zagadnień można jednak w znakomitej większości przypadków pozwolić sobie w sytuacji, gdy autor badania jest jednocześnie osobą gromadzącą dane, gdy badanie nie jest realizowane na zlecenie.

Trudne i kłopotliwe sytuacje terenowe

Najtrudniejsze sytuacje badawcze to te, kiedy podczas realizacji wywiadu pojawiają się osoby trzecie. Gdy umawiałam się na wywiady, podkreślałam, że rozmowa powinna odbywać się bez obecności osób trzecich. Nie wyobrażałam sobie prowadzenia wywiadu w obecności męża, partnera lub dziecka osoby badanej.

Znalazłam się jednak kilkakrotnie w sytuacji odbiegającej od tych ustaleń. Jeden z wywiadów realizowanych w Norwegii został nagle zakłócony pojawieniem się męża mojej rozmówczyni. Gdy zaczynałyśmy rozmowę, byłyśmy same, ale w międzyczasie mężczyzna wrócił z dziećmi do domu. Siedziałyśmy w kuchni, po dwóch stronach stołu. Mąż wszedł do kuchni i stanął za moimi plecami. Sytuacja stała się dla mnie bardzo kłopotliwa, miałam poczucie, że małżeństwo wymienia spojrzenia nad moją głową. Straciłam kontrolę nad przebiegiem wywiadu, nie czułam, że mogę zapytać o relacje małżeńskie po narodzinach dziecka z niepełnosprawnością. Kobieta nie zaproponowała mężowi, aby usiadł z nami przy stole. Nie poprosiła go również, aby zostawił nas same. On z kolei w ogóle nie sprawiał wrażenia zakłopotanego tą sytuacją. Wydawało mi się zatem, iż najlepszym rozwiązaniem będzie wcześniejsze zakończenie rozmowy. Byłam gościem w ich domu, nie czułam się uprawniona do tego, aby w jakiś sposób „zarządzać” sytuacją. 
Pomimo wielu rozmów z innymi badaczami, jakie przeprowadziłam po tym wydarzeniu oraz zdobyciu doświadczenia w zakresie realizacji trudnych wywiadów, cały czas nie mam pewności, jak powinnam zareagować w podobnej sytuacji.

Innym razem, osobie badanej towarzyszył dorosły syn z zespołem Downa. Również w tym wypadku sytuacja była dla mnie krępująca. Obawiałam się bowiem, że jakimś pytaniem mogę go urazić. Z drugiej strony, jego matka zupełnie nie przejmowała się jego obecnością, traktowała go jak duże dziecko, które nic nie rozumie. Zatem oprócz skrępowania, miałam poczucie, że nie akceptuję postawy matki wobec dorosłego syna. Ten wywiad był dla mnie szczególnie trudny.

Dwa razy przeprowadzałam rozmowę z dwojgiem rodziców. Mężczyźni bardzo chcieli rozmawiać, nie wyobrażałam sobie, że mogę ot tak poprosić ich o opuszczenie pokoju. Tym bardziej, że kobiety najwyraźniej nie miały nic przeciwko temu. Miałam poczucie, iż wykluczenie ich z wywiadu mogłoby zniechęcić ich żony, mogłam w ten sposób „spalić” rozmowę.

Okazało się, że to właśnie te wywiady należały do najbardziej interesujących, małżeństwa rozmawiały także ze sobą, dyskutowały, nie zgadzały się. Nie miałam wrażenia, że kobieta albo mężczyzna coś pomijają w rozmowie ze względu na obecność małżonka. Zatem mimo początkowych trudności, właśnie te wywiady uważam za bardzo udane.

\section{Podsumowanie}

Pranne Liamputtong (2007) podkreśla, iż w badaniach grup wrażliwych społecznie więcej uwagi powinno się przywiązywać do procesu badawczego, do tego, w jaki sposób badanie wpływa nie tylko na badanych, ale również na badacza. Zdajemy się zapominać o tym, że z każdym badaniem badacz staje się bogatszy w doświadczenia, nie tylko zawodowe, 
ale również emocjonalne, osobiste. Badania zmieniają nas, badaczy. Podejmowanie trudnych tematów sprawia, że ciągle czegoś się uczymy.

Żyjemy czasem w oderwaniu od rzeczywistości społecznej. Mamy tendencję do sprowadzania ludzkiego doświadczenia do liczb, procentów, czegoś policzalnego. $Z$ tym jest nam łatwiej sobie poradzić - zawodowo i emocjonalnie. Wydaje mi się, że brakuje nam refleksji nad rolą badacza, nad sposobami radzenia sobie z własnymi emocjami i trudnościami w badaniu wrażliwych grup.

Z perspektywy realizacji badań w grupie wrażliwej społecznie kluczowe jest pojęcie granic. Granice i ramy ma sama sytuacja badawcza, sytuacja realizacji pogłębionego wywiadu. Wytyczają je zobowiązania badacza, uprawnienia osób badanych ogólnie przyjęte i skodyfikowane zasady. Uzyskanie formalnej świadomej zgody na udział $\mathrm{w}$ badaniu pełni funkcję ochronną zarówno w stosunku do osoby realizującej badanie, jak i w stosunku do jego uczestników. Jednak ostrość i wyrazistość tych granic zależy od badacza i badanych, od kontekstu realizowanego wywiadu.

Gdzie kończy się wywiad socjologiczny, a zaczyna rozmowa (o znamionach rozmowy terapeutycznej)? Gdzie kończy się rola badacza, a zaczyna rola „przyjaciela”? Gdzie kończy się gromadzenie danych, a zaczyna zaangażowanie w sprawy badanych? Ile jako badacz daję od siebie, jak bardzo się odkrywa?

Tych kwestii nie da się skodyfikować, pozostają one w dyspozycji badacza i badanych.

Bibliografia

Becker H.S. (1967), Whose side are we on?, „Social Problems” Vol. 14 
Ciuk S., Latusek-Jurczak D. (2012), Etyka w badaniach jakościowych, (w:) Badania jakościowe. Podejścia i teorie. Tom I, (red.) Jemielniak D., Wydawnictwo Naukowe PWN, Warszawa

Chase S.E. (2009), Wywiad narracyjny. Wielość perspektyw, podejść, głosów, (w:) Metody badań jakościowych. Tom 2, (red.) Denzin N.K., Lincoln Y.S., Wydawnictwo Naukowe PWN, Warszawa

Creswell J.W. (2009), Qualitative Inquiry \& Research Design. Choosing Among Five Approaches, Sage Publications, Thousand OaksLondon-New Delhi

Flick U. (2010), Projektowanie badania jakościowego, Wydawnictwo Naukowe PWN, Warszawa

Liamputtong P. (2007), Researching the Vulnerable. A Guide to Sensitive Research Methods, Sage Publications, London-Thousand OaksNew Delhi

Lofland J., Snow D.A., Anderson L., Lofland L.H. (2009), Analiza układów społecznych. Przewodnik metodologiczny po badaniach jakościowych, Scholar, Warszawa

Niedbalski J. (2009), Niepelnosprawność intelektualna $w$ perspektywie badań socjologicznych. Rozważania nad zastosowaniem metod jakościowych, (w:) Metody, techniki i praktyka badań społecznych, (red.) Bąk A., Kubisz-Muła Ł., Wydawnictwo Akademii TechnicznoHumanistycznej, Bielsko-Biała

Sałkowska M. (2015), Matka Downa. Piętno. Znaczenia. Strategie, Zakład Wydawniczy NOMOS, Kraków

Surmiak A. (2016), Wybrane problemy etyczne $w$ naukowych badaniach na zlecenie. Refleksje etnografki, „Przegląd Socjologii Jakościowej”, t. 12, nr 3, http://www.qualitativesociologyreview.org/PL/ Volume35/PSJ_12_3_Surmiak.pdf

Thoits P.A. (2011), Resisiting the Stigma of Mental Illness, „Social Psychology Quarterly” Vol. 74, No. 6 